\title{
Design and Realization of Project-based Computer English Learning System
}

\author{
https://doi.org/10.3991/ijet.v12.i08.7147 \\ Li Qin \\ Jilin Institute of Chemical Technology, Jilin, China \\ missqinli@qq.com
}

\begin{abstract}
This paper describes the design principles and realization process of project-based computer English learning system. The subjective initiative of project-based learning is applied to English learning as a starting point, allowing full play to learner's analytical, problem-solving and self-exploration ability. Combined with the computer database SQL Server and other related procedures, we established an English project-based learning system, investigated its user satisfaction and collected relevant statistics. This system plays a promotive role in providing guidance for English learning and lifting the informatization level of English teaching.
\end{abstract}

Keywords—project-based learning, English learning, project-based learning system, computer database.

\section{Introduction}

Informatization is the big trend of global economy and development, and the degree of informatization in China's education field is increasing year by year. In order to adapt to the new perspective of basic education reform proposed by the central government, more and more Chinese scholars have paid attention to the field of informatization research in the education industry [1]. Among them, the education of English learning tends towards informatization and internationalization. English education and training institutions such as New Oriental and Wall Street provide more alternatives of English learning. In the process of school education, the traditional teaching mode is still widely used in China's English teaching, which not only deviates from the trend of educational informatization, but also fails to adapt to English learning and other disciplines that require highly-valued and active involvement between learners and teachers [2].

Despite its obvious advantages in cultivating students' self-exploration and cooperative learning ability, project-based learning is not functional in classroom teaching in a genuine sense, because it fails to satisfy the requirements of comprehensive learning, investigative study, and collaborative learning [3]. Project-based learning is an emphasis on the cultivation of learner's comprehensive ability in practice, but it is difficult for classroom teaching to meet the demands for learning resources. Against this background, the development of informatization provides for the implementation 
of project-based learning based on network platform which is centered on computer technology, multimedia technology and network technology [4].

The development of computer-based English learning system is to improve the degree of involvement and informatization of English learning. Based on computer database technologies and project-based learning, we realized the organic combination of curricular and extracurricular English learning on the platform of our system. In this way, the system helps in fostering learners' capacity of independent thinking and problem analysis, and strengthens the sense of existence on educator's side and the sense of involvement on learner's side. This new model of learning is an organic integration of computer information technology with curriculums.

\section{The overview of basic theories and technologies of project- based learning}

\subsection{Concept definition}

Project-based learning (abbreviated for PBL), also known as project teaching method or project teaching, is usually defined as a teaching method that helps learners acquire knowledge and skills involved in working projects and develops their learning ability in this process [5]. With the all-in-one (teaching, learning and acting) characteristics, project-based learning is more functional in courses of practical ability. In teaching practice, all technological products and services are project alternatives, which combines theoretical knowledge acquisition with practical ability development, so that cultivating learners' hands-on ability and the ability to find, analyze and solve problems. As a new learning mode, project-based learning consists of contents, community, activities, context and products [6].

\subsection{The comparison between project-based learning and traditional teaching mode}

The basic elements of teaching include: teachers, learners and learning content. Instead of independence and irrelevance, they are intertwined and interacting as a whole [7].

The traditional teaching mode is centered on "transmitting-accepting" or Herbartianism: stimulate learning motivation - do revision - teach new knowledge - to consolidate and use new knowledge - to check and evaluate. In the traditional teaching mode, the teacher is the center of teaching, who spreads and imparts knowledge to learners linearly and controls the teaching process in the full sense. Learners can only passively accept the teaching content taught by teachers, thus becoming less enthusiastic and provocative in exploring knowledge. The learning result is aimed at cramming for teaching materials [8].

In the project-based learning model, teachers act more as a guide and organizer, while learners are the involver and self-designer of a project. Learners finish projects at all stages according to self-interest and learning habits, in whose process the practi- 
cal ability is enhanced. When cultivating learners' learning initiatives, project-based learning also provide phased objectives for learners to choose from, converting learning achievements into project results. Therefore, project-based learning has become the priority for many schools and educational institutions to foster skilled individuals.

\section{Project-based learning system software development technology}

\section{1 .Net Framework}

Server software are those that operate in C / S or B / S. We applied .NET-based Web server is mainly applied to our system proposed in this paper [9]. Considering that we have Windows system as the operating system of the Server, in which .NET Framework is used, we will focus on the application of .NET Framework. It lays foundation for the construction of a new-generation operating system with Internet itself, and expands the design thought of Internet and operating systems. As a result, designers can create application procedures independent of equipment, which realizes Internet connection in an easier way [10]. The structure of .Net framework is shown in Fig. 1.

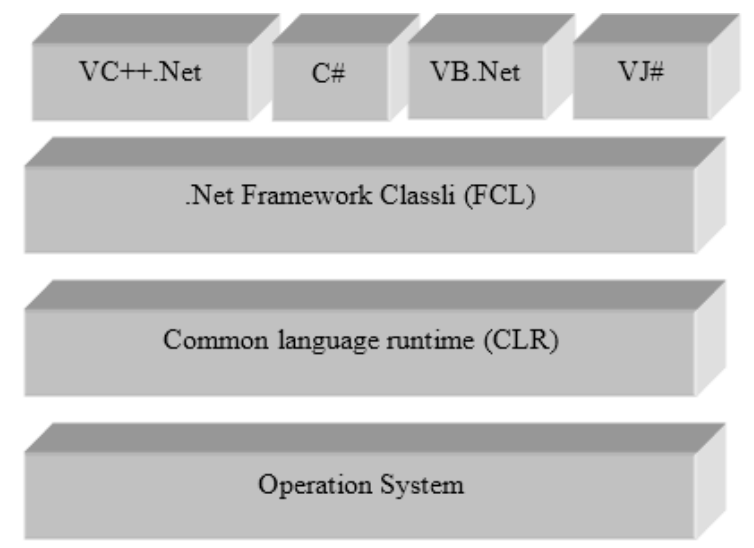

Fig. 1. .Net Framework architecture

\subsection{Database technology}

Database is "a warehouse that organizes, stores, and manages data according to the data structure." Some of the frequently-used databases are IBM's DB2, Oracle, FoxPro database, Access database, mySQL, SQL Server. Among them, SQL Server database receives a wide range of applications because of its graphical user interface and powerful programming language [11]. SQL Server is a relational database management system (DBMS) developed and promoted by Microsoft, which was originally co-developed by Microsoft, Sybase, and Ashton-Tate [12]. 
Based on the knowledge and analysis of the above technologies, we realized the openness of our project-based learning system in combination with SQL Server and data access layer. Net.

Table 1. List of project system development program

\begin{tabular}{ll}
\hline \multicolumn{1}{c}{ Classification } & Name \\
Server & Web Server \\
\hline Platform Components & NET FRAMEWORK \\
\hline Database & sql server \\
\hline Data Access Layer & ADO.NET \\
\hline application development & ASP.NET \\
\hline Business logic (background coding language) & C\#writing \\
\hline
\end{tabular}

\section{The design of project-based learning computer English learning system}

\subsection{Requirement analysis of the project-based learning system}

With the development of internet technology, internet learning has been popularized because of its convenient and diversified services. What project-based learning system trains is learners' self-learning ability, for which more emphasis is paid on the development of their hobbies and interests. The online platform learning meets such requirements of project-based learning. The computer English learning system mainly serves for on-campus students' needs of English assisted learning. By using this system, teachers assign projects to students to cultivate their English competence, in a way that is more targeted and phased-goal-oriented [13].

Based on requirement analysis, we somewhat abstracted a variety of system roles into a data model, so that forming a conceptual model. Table 2 lists the system privilege assignment results.

Table 2. System privilege assignment results

\begin{tabular}{|c|c|c|}
\hline Item & Role Name & Function and permissions \\
\hline 1 & Administrator & $\begin{array}{l}\text { Management of the project module; project role division; evaluation of } \\
\text { project results; participation in the exchange of discussion. }\end{array}$ \\
\hline 2 & Project Leader & $\begin{array}{l}\text { Register the basic information, create a project repository, assign, manage } \\
\text { project tasks }\end{array}$ \\
\hline 3 & Project member & $\begin{array}{l}\text { Register the basic information, Complete project assignment, manage } \\
\text { project tasks }\end{array}$ \\
\hline
\end{tabular}

\subsection{The design of the project-based learning management module}

After the logic program design of internal programs is used to complete the matching of system requirement analysis [14], the to-be-designed system modules need to 
clarify the role of each project member and the procedure of project execution in the form of framework [15], as shown in Fig. 2.

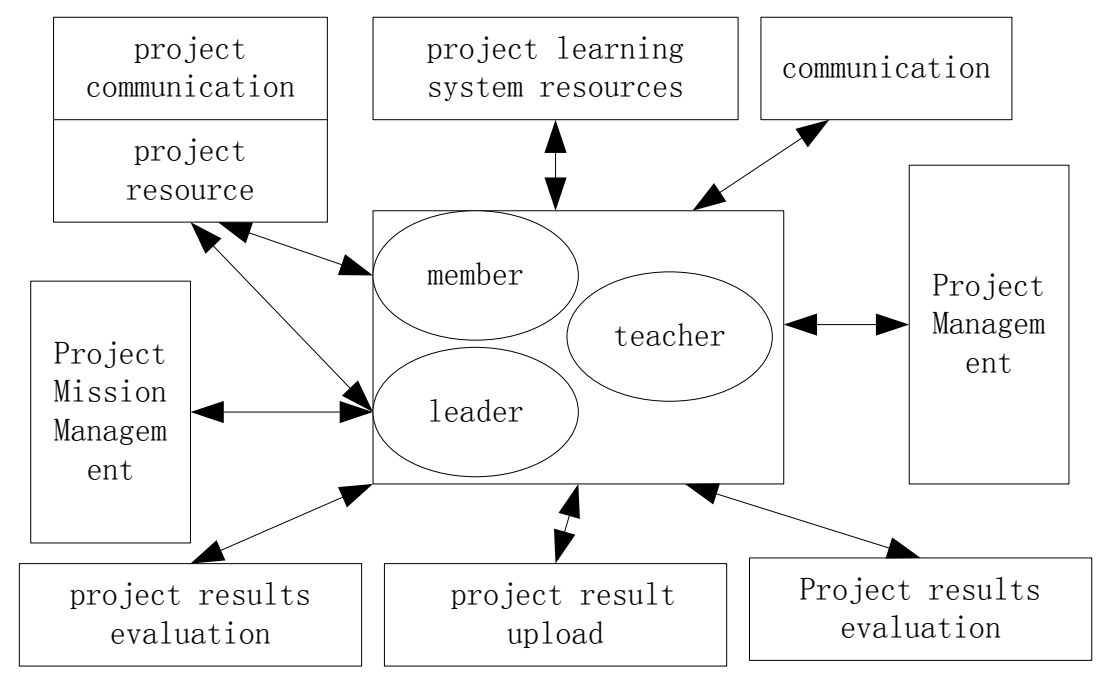

Fig. 2. The diagram of the project-based learning system structure

There are three roles played in the project-based computer English learning system: teacher or administrator, project leader, and project member. Teachers can serve as administrator, the role of project leader can be established according to actual situations, and project members are learners participating in system projects. Then we completed the design of the project-based learning system by designing project communication module, theme discussion module, project discussion module, and project result management module.

\subsection{The implementation of the functional modules of the project-based learning management system}

Implementation of user registration module. To participate in the project-based learning computer learning system, project members should first log on the system, register as one of the three system roles, and remember user names and passwords [16]. The log-on module interface is the only access to learners, teachers and administrators as registered, as shown in Fig. 3.

Implementation of project management module. The purpose of the learner is to learn English better. System management tasks are in the charge of teachers and administrators, including system creation, project state management, and the management of project team members. Fig. 4 is the project management module after logging on.

Fig. 5 is the interface of the system in creating a project. Through the description of project contents and the starting time, the administrator can better monitor the progress of project execution and the status of project members in the system. 
Paper-Design and Realization of Project-based Computer English Learning System

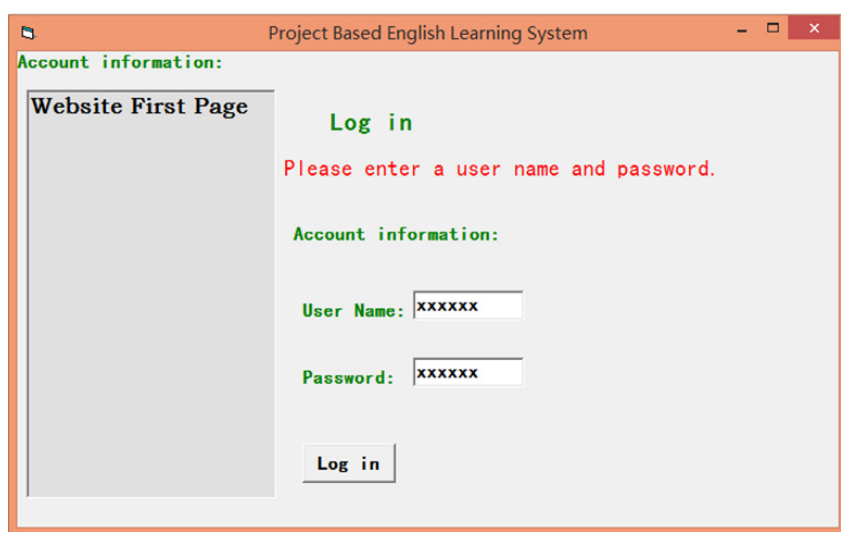

Fig. 3. User login interface display

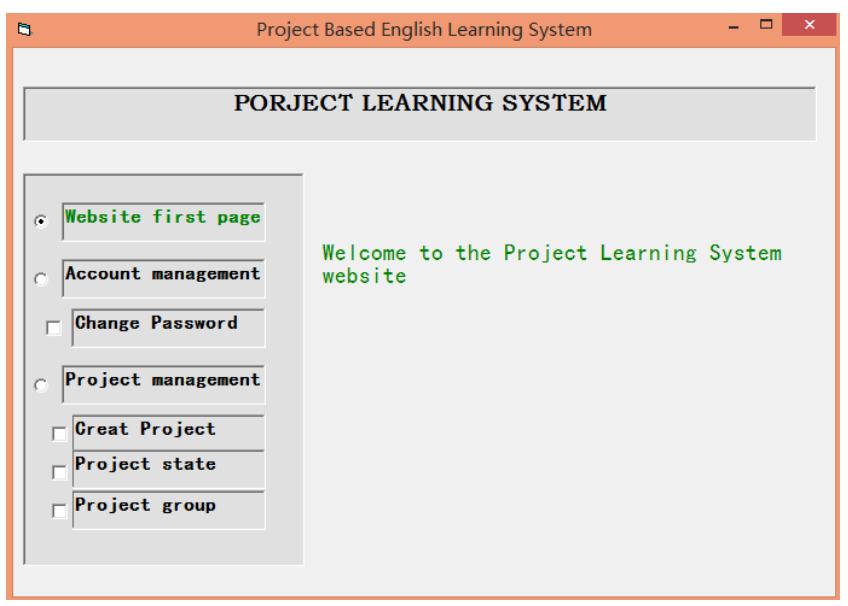

Fig. 4. Project management module

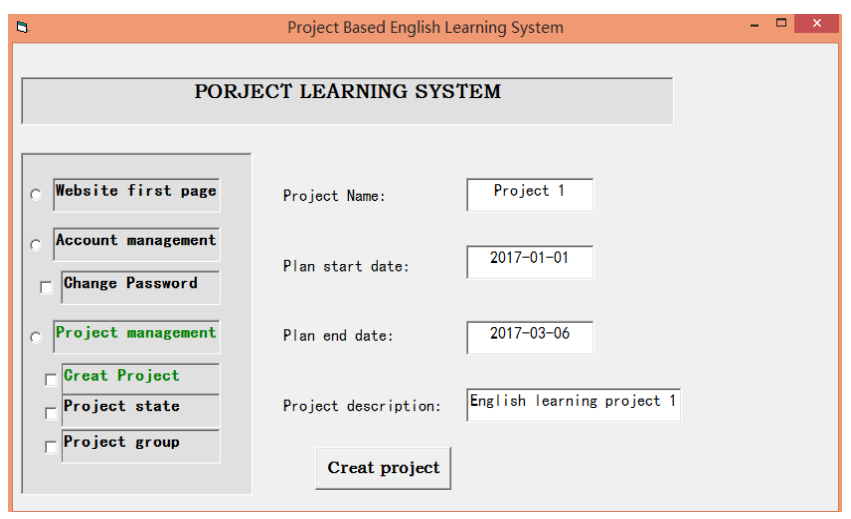

Fig. 5. Project creation module 
Then the project module is designed as scheduled. The project-based computer English learning system is implemented after completing the design of these function modules: project resource management, project content exchange, project result submission, and project result evaluation.

\subsection{Survey of user satisfaction of the project learning management system}

The general steps of project-based learning are: select projects, formulate learning plans, study and inquiry, display and evaluate project results. In order to better verify the effectiveness and feasibility of the project-based English learning system, it is inevitable to conduct research on practical teaching. To this end, we applied our system to the English learning of 80 students (Grade 2015) in the Department of Automation in a college in Chengdu, and formulated customer-made learning schemes with the assistance of teachers. We followed the general steps of project-based learning to launch the practical analysis of our system.

The project was completed in two months, with the active participation and task fulfillment of every project member. By referring to the mode of teaching evaluation, we assessed the instructional objective completion level, the instructional value and other indices of the English learning system. Table 3 is a feedback questionnaire for the project-based learning system.

Table 3. Feedback questionnaire of the project-based learning system

\begin{tabular}{l|c|c|c}
\hline \multicolumn{1}{c}{ Evaluation index } & \multicolumn{3}{c}{ Project participants(80) } \\
In your system for the time distribution of & In-class & Outside class & Both \\
learning English & 5 & 12 & 63 \\
\hline Through the use of project learning system, & High & General & No affect \\
your interest in teaching content & 59 & 21 & 0 \\
\hline \multirow{2}{*}{$\begin{array}{l}\text { Which of the following teaching models do you } \\
\text { like? }\end{array}$} & Class teaching & $\begin{array}{c}\text { Class teaching }+ \\
\text { training }\end{array}$ & $\begin{array}{c}\text { Class teaching } \\
\text { +project learing }\end{array}$ \\
\cline { 2 - 4 } & 0 & 18 & 62 \\
\hline $\begin{array}{l}\text { Do you think the system's resource manage- } \\
\text { ment is reasonable? }\end{array}$ & Reasonable & General & Be to improved \\
\cline { 2 - 4 } & 35 & 55 & 0 \\
\hline $\begin{array}{l}\text { Through the use of the system, do you think the } \\
\text { system is helpful for your English study? }\end{array}$ & Yes & General & None \\
\cline { 2 - 4 } & 52 & 28 & 0 \\
\hline
\end{tabular}

Through the above table, we can see from the teacher's point of view that: the system saves class time because teachers have the alternatives to employ the finite time for an in-class instruction and analysis of knowledge scopes; meanwhile, the system learning software acts as the extension of courses in the sense of teacher-student communications. From the student's point of view: students utilize extra-curricular time well with our system; not only can they learn more knowledge than otherwise in the project planning time, but they are possible to be more subjective and creative in English learning, which is different from the traditional mode of passive classroom learning. In addition, the results of the survey show that project-based learning helps 
students be more interested in English learning materials and that the mode of resource distribution obtains the acceptance of most of the surveyed project members. From a comprehensive perspective, 52 of all the survey participants considered that the project-based computer learning system was effective, and the percentage of effectiveness reached $65 \%$.

\section{Conclusion}

With project-based learning as the theoretical basis, this paper used computer program software such as .Net Framework and database SQL server to complete the design and implementation of the computer learning system. To address the problems of poor initiatives and lack of reasonable time arrangement for students in English learning, we assigned project tasks of English learning to learners at fixed time and in fixed quantity, because project-based learning can render learners more proactive and communicative. Learners should learn English, communicate with teachers and submit project results within the required time. In the result evaluation process, the English learning results are checked. Finally, the result of practical application shows that the feedback and evaluation of the design and implementation of the project-based computer learning system are high. It is concluded that the learning system has the following characteristics:

1. By reviewing literatures on theories of project-based learning, we successfully applied the theory of project-based learning to English learning, which is of certain novelty in learning design.

2. This learning aid provides a comprehensively controllable platform for both learners and educators.

3. The project-based English learning system not only cultivates the initiative of learners, but also improves their collaborative ability and practical ability.

\section{Acknowledgment}

Project of Social science fund project of Jilin Province: Research of constructing teaching mode in flipped classroom of college English under digitized circumstances (No. 2015wy13).

\section{$7 \quad$ References}

[1] Mills, J. E., Treagust, D. F. (2003). Engineering education, is problem-based or projectbased learning the answer. Australasian Journal of Engineering Education, 3(4), 205-207.

[2] Macias-Guarasa, J., Montero, J. M., San-Segundo, R., Araujo, A. (2006). A project-based learning approach to design electronic systems curricula. IEEE Transactions on Education, 49(3), 389-397. https://doi.org/10.1109/TE.2006.879784 
Paper-Design and Realization of Project-based Computer English Learning System

[3] Jollands, M. (2012). Project-based learning as a contributing factor to graduates' work readiness. European Journal of Engineering Education, 37(2), 1-12. https://doi.org/10.1080/03043797.2012.665848

[4] Kumar, A., Fernando, S., Panicer, R. C. (2013). Project-based learning in embedded systems education using an FPGA platform. IEEE Transactions on Education, 56(4), 407-415. https://doi.org/10.1109/TE.2013.2246568

[5] Qidwai, U. (2011). Fun to learn: project-based learning in robotics for computer engineers. Acm Inroads, 2(1), 42-45. https://doi.org/10.1145/1929887.1929904

[6] Ho, M. L., Rad, A. B., Chan, P. T. (2004). Project-based learning - design of a prototype semiautonomous vehicle. IEEE Control Systems, 24(5), 88-91. https://doi.org/10.1016/ j.ijproman.2009.10.006

[7] Daradoumis, T., Xhafa, F., \& Marques, J. M. (2002). A methodological framework for project-based collaborative learning in a networked environment. International Journal of Continuing Engineering Education and Life-Long Learning(5-6), 389-402. https://doi.org/10.1007/1-4020-7909-5 3

[8] Day, J., Lou, H., Slyke, C. V. (2004). Instructors' experiences with using groupware to support collaborative project-based learning. International Journal of Distance Education Technologies, 2(3), 11-25. https://doi.org/10.4018/978-1-59904-935-9.ch035

[9] Grippa, F., Secundo, G. (2009). Web 2.0 project-based learning in higher education: some preliminary evidence. International Journal of Web Based Communities, 5(4), 543-561. https://doi.org/10.1504/IJWBC.2009.028089

[10] Duffy, J. (2006). Professional. net framework 2.0. Journal of Medical Entomology, 7(6), 459-69.

[11] Lewis, M. (2004). Database Security in SQL Server 7.0 and 2000. SQL Server Security Distilled. Apress. https://doi.org/10.1007/978-1-4302-0663-7 4

[12] Gkolia, Chrysanthi, Jervis, Alan. (2002). Teachers' and pupils' perceptions of the use of integrated learning systems in english and mathematics education. Lancet, 352(9122), 98101.

[13] Kang, Y., Chen, G., Cheng, Y., Xu, L. (2004). Design and realization of network teaching platform based on e-learning. IEEE Transactions on Consumer Electronics, 50(3), 962967. https://doi.org/10.1109/CSSE.2008.218

[14] Sun, C. Y., Chang, K. Y. (2016). Design and development of a location-based mobile learning system to facilitate english learning. Universal Access in the Information Society, 15(3), 345-357. https://doi.org/10.1007/s10209-014-0392-x

[15] Qingli, Zhao. (2013). Design and application of english learning system based on b/s structure. International Journal of Technology Management, 97-99. https://doi.org/10.2495/ GCN131132

[16] Zou, Q. C., Campus, H. B., University, B. O. (2006). Design and realization of the learning environment of "the multimedia application base" on the platform of moodle. Canadian Journal of Chemical Engineering, 84(3), 310-315.

\section{Authors}

Li Qin is a lecturer in School of Foreign Languages, Jilin Institute of Chemical Technology Jilin 132022, China. She mainly engage in International and comparative education (missqinli@qq.com).

Article submitted 10 May 2017. Published as resubmitted by the authors 21 June 2017. 